\title{
PURPOSE A SACRED ROOM OF CHRUCHES BY PASTOR MANGUNWIJAYA CASE STUDY: CHURCH OF MARIA ASSUMPTA KLATEN, CHURCH OF THERESIA SALAM, AND CHURCH OF MARY
}

\author{
${ }^{1}$ Maria Angelina Tanumihardja. ${ }^{2}$ Yenny Gunawan, ST., MA \\ ${ }^{1}$ Student in the Bachelor's (S-1) Study Program in Architecture \\ at Parahyangan Catholic University \\ ${ }^{2}$ Senior lecturer in the Bachelor's (S-1) Study Program in Architecture \\ at Parahyangan Catholic University
}

\begin{abstract}
Sacred space is everywhere and has become the part of human's life since thousand years ago. One manifestation of the sacred space is the Catholic Church. A sacred space in the Catholic Church should be able to accommodate liturgical activities in accordance with the rules and the order of their activities so the celebration of the Eucharistic liturgy can run well. This study will attempt to understand the concept and the manifestation of the sacred space found in Romo Mangunwijaya's churches in accordance to the concept and the manifestation of the Catholic Church's sacred space.

Research will be carried out based on a preliminary study conducted by studying the universal sacred space theory proposed by Eliade and the theory of the Catholic Church's sacred space that refers to the principles of the liturgy space. Results of analysis of each object of the study will then be processed further through a comparison table so that it can be concluded the manifestation of a sacred space in Romo Mangunwijaya's churches.

From the results of research on the objects of the study, showed that the manifestation of the sacred space of the Romo Mangunwijaya's Churches dominantly shown in terms of orientation, ornaments, and atmosphere. In addition, the case study that shows the most dominant manifestation of the sacred space is Theresia Salam Church.

The benefits of this research are: for general public, this research can improve the knowledge of the importance of the sacred space within the Catholic Church and how to integrate local values and culture into the sacred space concept established in the Catholic Church's rules. Meanwhile, for the architects and institutions of the Catholic Church, this research can improve the knowledge of the concept of sacred space in the Catholic Church and how to manifest the concept of the sacred space into the architecture of the Catholic Church.
\end{abstract}

Key Words: sacred space, church, Y.B. Mangunwijaya

\section{PERWUJUDAN RUANG SAKRAL GEREJA-GEREJA KARYA ROMO MANGUNWIJAYA KASUS STUDI: GEREJA MARIA ASSUMPTA KLATEN, GEREJA THERESIA SALAM, DAN GEREJA MARIA SAPTA DUKA MENDUT}

\author{
${ }^{1}$ Maria Angelina Tanumihardja. ${ }^{2}$ Yenny Gunawan, ST., MA \\ ${ }^{1}$ Mahasiswi S1 Program Studi Arsitektur Universitas Katolik Parahyangan. \\ 2 Dosen Pembimbing S1 Program Studi Arsitektur Universitas Katolik Parahyangan.
}

\begin{abstract}
Abstrak- Ruang sakral ada dimana-mana dan telah menjadi bagian dari kehidupan manusia sejak ribuan tahun lalu. Salah satu bentuk perwujudan ruang sakral adalah Gereja Katolik. Ruang sakral dalam Gereja Katolik harus dapat menampung kegiatan liturgi sesuai dengan kaidah dan urutan kegiatannya agar perayaan liturgi Ekaristi dapat berjalan dengan baik. Penelitian ini akan berusaha membuka pemahaman mengenai konsep dan perwujudan ruang sakral yang terdapat pada gereja-gereja karya Romo Mangunwijaya jika ditinjau dari konsep dan perwujudan ruang sakral Gereja Katolik universal.
\end{abstract}

${ }^{1}$ Corresponding Author: aline.angelina1412@gmail.com 
Penelitian akan dilakukan berdasarkan studi awal yang dilakukan dengan mengkaji teori ruang sakral universal yang diajukan oleh Eliade dan teori ruang sakral Gereja Katolik universal yang merujuk pada prinsip-prinsip ruang liturgi. Hasil analisa masing-masing obyek studi kemudian akan diolah lebih lanjut melalui tabel perbandingan sehingga dapat disimpulkan perwujudan ruang sakral pada gereja karya Romo Mangunwijaya.

Dari hasil penelitian pada ketiga obyek studi, didapatkan hasil bahwa perwujudan ruang sakral Gereja karya Romo Mangun paling kuat ditunjukkan dari segi orientasi, ornamen, dan suasana. Selain itu, obyek studi yang menampilkan perwujudan ruang sakral paling kuat adalah Gereja Theresia Salam.

Manfaat dari penelitian ini adalah sebagai berikut: bagi kaum umum, penelitian ini dapat menambah pengetahuan mengenai pentingnya ruang sakral dalam Gereja Katolik serta bagaimana mengintegrasikan nilai dan budaya setempat ke dalam konsep ruang sakral yang telah ditetapkan dalam aturan Gereja Katolik. Sementara itu bagi para arsitek dan lembaga Gereja Katolik, penelitian ini dapat menambah pengetahuan mengenai konsep ruang sakral dalam Gereja Katolik serta bagaimana mewujudkan konsep ruang sakral tersebut ke dalam arsitektur Gereja Katolik.

Kata kunci: ruang sakral, gereja, Y.B. Mangunwijaya

\section{PENDAHULUAN}

Ruang sakral merupakan ruang tempat berlangsungnya peristiwa sakral. Lebih lanjut lagi, ruang sakral merupakan ruang yang memiliki ritme tertentu, keberadaan yang kuat, dan karakter khusus yang membuat ruang tersebut memiliki kualitas yang berbeda dari ruang lainnya (yang tidak sakral). Ruang sakral telah ada sejak ribuan tahun yang lalu. Keberadaan ruang sakral berbeda pada setiap kepercayaan dan budaya, namun secara umum ruang sakral memiliki ciri-ciri diantaranya adalah: terdapat tanda/simbol tertentu, memiliki orientasi terpusat, dimana pusat dari orientasi tersebut adalah ruang sakral itu sendiri (Eliade, 1957, p.21), serta memiliki perbedaan kualitas ruang dari ruang-ruang lainnya (yang tidak sakral).

Jika membicarakan mengenai ruang sakral, maka tidak akan terlepas dari axis mundi dan geometri sakral. Axis mundi merupakan sumbu imajiner yang menghubungkan tiga entitas secara vertikal, yaitu: surga (heaven), dunia (world), dan neraka (under world). Konsep axis mundi ini telah diyakini oleh berbagai agama dan budaya sebagai pilar universal yang menopang surga dan dunia dan memiliki dasar di bawah dunia serta menjadi pusat dari dunia itu sendiri. Dengan demikian dapat dikatakan bahwa axis mundi merupakan pusat dari kesakralan tersebut berada dan menjadi penentu hirarki dan tatanan ruang (Eliade, 1957, p.37). Tatanan ruang tersebut sendiri dapat membentuk axis sakral baik berupa axis vertikal maupun horisontal yang masing-masing memiliki makna tersendiri dan menentukan tingkatan ruang sakral. Selain axis mundi, bentuk-bentuk geometri sakral juga mempengaruhi pembentukan ruang sakral. Geometri sakral telah ada sejak ribuan tahun lalu dan telah digunakan untuk membentuk arsitektur sakral (Srisadono, 2013). Geometri sakral penting untuk menghadirkan unsur simbolisme dalam ruang sakral serta dapat juga mempengaruhi tatanan ruang dan orientasi bentuk bangunan dan ruang dalam bangunan.

Salah satu wujud arsitektur sakral adalah Gereja Katolik. Arsitektur Gereja Katolik dalam perkembangannya telah mengalami berbagai perubahan dari masa ke masa, mulai dari arsitektur Katakombe, Byzantium, Romanesk, Gotik, Renaisans, Barok, dan Rokoko, hingga arsitektur gereja modern dan post-modern. Perubahan yang paling signifikan terjadi setelah Konsili Vatikan II yaitu terjadinya perubahan makna dari gereja itu sendiri yang mempengaruhi proses liturgi yang berlangsung di dalamnya. Setelah Konsili Vatikan II, gereja mengalami perubahan pemaknaan dari "rumah Tuhan" menjadi "rumah umat Tuhan" sehingga bentuk gereja tidak harus melambangkan Ketuhanan yang kuat melainkan dapat lebih bersifat melayani umat.

Dalam Konsili Vatikan II dibahas juga tentang pentingnya penyisipan kebudayaan lokal sebagai bagian dari liturgi dengan tetap tidak mengurangi nilai-nilai utama dari proses liturgi itu sendiri. Beberapa perubahan makna tersebut membuat bentuk bangunan dan 
tatanan ruang gereja tidak sekaku sebelumnya, namun hal ini juga yang dapat menyebabkan munculnya berbagai interpretasi yang berbeda-beda dari perubahan tersebut dan seringkali gagal dalam perwujudannya menjadi sebuah bangunan gereja yang tetap sakral. Paus Benedictus XVI menyatakan bahwa ada peristiwa desakralisasi arsitektur Gereja Katolik yang terjadi di berbagai tempat di dunia. Hal ini terjadi karena kurangnya pemahaman mengenai konsep dan perwujudan kesakralan dalam sebuah Gereja Katolik sehingga terjadi ketidaksesuaian penataan ruang-ruang dengah kaidah liturgi yang seharusnya.

Bagian yang esensial dalam agama Katolik adalah liturgi, dimana dalam liturgi terjadi suatu perayaan iman dengan gereja sebagai wadahnya. Oleh karena itu gereja harus dapat menampung liturgi dengan segala kaidah dan tatanannya agar proses liturgi dapat berjalan dengan baik dalam suasana yang sakral sehingga manusia dapat menghayati perjumpaan dirinya dengan Tuhan. Lettourgia adalah kata Yunani yang berarti "pelayanan publik". Pusatnya adalah ekaristi: pertemuan partisipatif umat dengan Allah (Subagio, 1997, p.6). Karenanya untuk selanjutnya jika membicarakan liturgi, maka akan difokuskan pada liturgi Ekaristi.

Pembaruan dalam liturgi Ekaristi boleh dilakukan terutama agar liturgi tersebut dapat diterima dengan mudah oleh masyarakat dan memiliki identitas lokal masyarakat tersebut. Dalam melakukan pembaruan liturgi terdapat aspek-aspek yang harus diperhatikan antara lain: aspek penyembahan kepada Allah, aspek pengajaran, Yesus Kristus, keunggulan Alkitab, keikutsertaan umat, aspek perubahan, serta aspek pembaruan dan kreativitas (Lolo, 2011). Sementara itu, pembangunan bangunan gereja dan pembentukan ruang liturgi hendaknya mengikuti tiga prinsip, antara lain adalah prinsip kesatuan, prinsip fungsi dan peran serta, serta prinsip simbolisme (Martasudjita, 1998). Prinsip simbolisme diwujudkan salah satunya melalui simbol liturgi yang dapat ditampilkan melalui beberapa wujud yaitu benda, gambar, maupun tulisan (Windhu, 1997). Simbol liturgi haruslah memuat makna yang juga bermakna liturgis sehingga ruang liturgi semakin kuat keberadaannya.

Dari konsep ruang sakral Gereja Katolik yang telah diurai pada pernyataan sebelumnya, dapat dibuat suatu perwujudan ruang sakral Gereja Katolik ke dalam arsitektur. Perwujudan ini didasarkan atas adanya kebutuhan ruang untuk menampung pelaksanaan liturgi dan ekspresi fisik yang dapat membangun suasana kesakralan. Rangkuman konsep ruang sakral yang telah dipaparkan sebelumnya dapat diwujudkan menjadi lima perwujudan, yaitu: 1) tatanan ruang sakral, 2) orientasi sakral, mencakup orientasi eksterior dan interior, 3) proporsi, 4) ornamen sakral, dan 5) suasana sakral (Suryanugraha, 2006, p.53). Perwujudan ini tidak dapat dilepaskan dari perwujudan liturgi dalam tata cara upacara Ekaristi sebagai landasan utama serta memperhatikan tiga prinsip ruang liturgi yang telah dipaparkan pada paragraf sebelumnya.

Penelitian mengenai kajian ruang sakral gereja-gereja Katolik karya Romo Mangunwijaya dilakukan untuk memahami konsep dan perwujudan ruang sakral Gereja Katolik universal serta perwujudannya dalam arsitektur Gereja Katolik karya Romo Mangunwijaya. Gereja Katolik karya Romo Mangunwijaya dipilih karena Romo Mangunwijaya merupakan salah satu arsitek Indonesia yang dengan gamblang menyatakan kesadarannya dalam menerapkan konsepsi Gereja menurut Konsili Vatikan II dalam desainnya. Hal tersebut diungkapkan dalam buku Peringatan 25 Tahun Gedung Gereja Maria Assumpta dan 70 Tahun Paroki Klaten. Pemilihan objek dilakukan dengan pertimbangan-pertimbangan sebagai berikut: merupakan Gereja Katolik karya Romo Mangun sebagai seorang arsitek rohaniwan, terletak di Jawa Tengah sehingga dapat dikaji juga aspek budaya Jawa yang mungkin disisipkan dalam desain arsitekturnya, serta lokasi ketiga bangunan yang relatif berdekatan sehingga memudahkan untuk melakukan survey dan pengumpulan data. Dari beberapa pertimbangan tersebut maka dipilihlah tiga objek studi 
yaitu Gereja Maria Assumpta di Klaten, Gereja St. Theresia Salam di Magelang dan Gereja Maria Sapta Duka di Mendut.

\section{METODOLOGI PENELITIAN}

Penelitian bersifat kualitatif dengan metode deskriptif-interpretatif dan perbandingan. Penelitian berawal dari dilakukannya studi literatur yang terkait dengan ruang sakral dan Gereja Katolik. Dari studi literatur yang dilakukan kemudian akan dilakukan pengolahan dan penyeleksian data sehingga didapatkan teori mengenai konsep ruang sakral universal, konsep ruang sakral Gereja Katolik, serta perwujudan konsep tersebut pada arsitektur Gereja Katolik. Konsep dan prinsip-prinsip tersebut kemudian akan dirumuskan dalam suatu indikator yang digunakan untuk menganalisis obyek studi dalam penelitian ini, yaitu gereja-gereja Katolik karya Romo Mangunwijaya (Gereja Maria Assumpta Klaten, Gereja Maria Sapta Duka Mendut, dan Gereja Theresia Salam).

Analisis pada obyek studi dilakukan dengan mengurai bagian-bagian pada bangunan tersebut sesuai dengan indikator yang telah dibuat (meliputi tatanan ruang, orientasi, proporsi, ornamen sakral, dan suasana sakral) serta mengidentifikasi setiap makna serta peran masingmasing bagian tersebut ke dalam pembentukan ruang sakralnya. Dari masing-masing hasil analisa obyek studi, kemudian akan dibandingkan satu dengan yang lain melalui tabel perbandingan sehingga didapatkan persamaan dan perbedaan konsep ruang sakral yang diterapkan pada masing-masing obyek studi serta dapat ditarik kesimpulan mengenai perwujudan ruang sakral pada gereja-gereja Katolik karya Romo Mangunwijaya.

\section{ASPEK RUANG SAKRAL PADA GEREJA KARYA ROMO MANGUNWIJAYA}

\subsection{TATANAN RUANG SAKRAL}

\section{Gereja Maria Assumpta Klaten}

Terdiri dari narthex, nave, dan sanctuary. Bagian nave pada Gereja Maria Assumpta terbagi menjadi dua bagian yang terpisahkan oleh elevasi lantai dan perbedaan penggunaan atap.
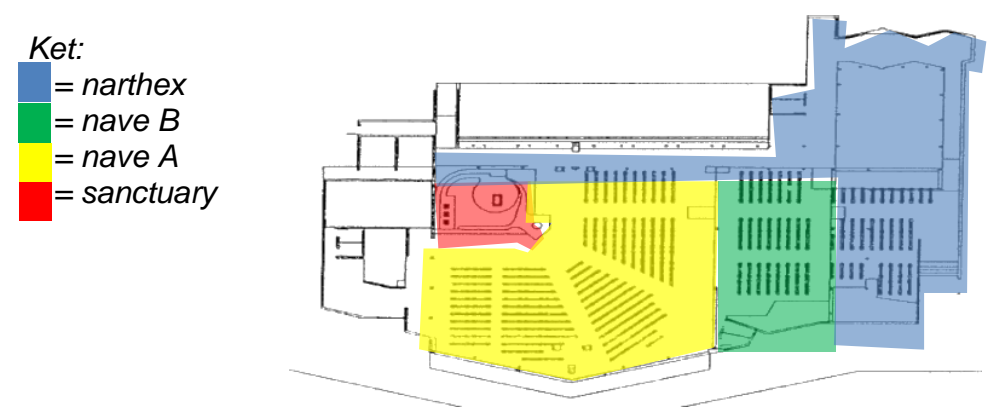

Figur 1. Pembagian tatanan ruang Gereja Maria Assumpta Klaten

Pada Gereja Maria Assumpta pembedaan kualitas ruang dilakukan dengan berbagai cara, salah satunya adalah dengan pembedaan elevasi lantai, dimana elevasi lantai tertinggi terletak pada bagian sanctuary sebagai area paling sakral dalam tatanan ruang dalam Gereja Katolik. 


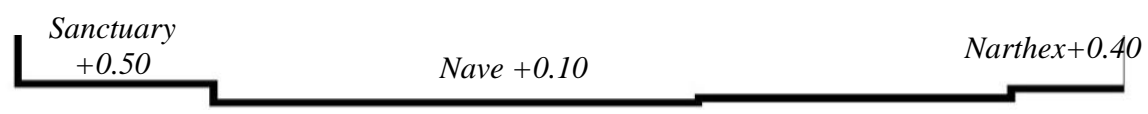

Figur 2. Perbedaan elevasi lantai pada narthex, nave, dan sanctuary

Pembedaan lainnya dilakukan melalui pembedaan material plafon pada area narthex dan area nave serta panti imam dimana pada area narthex/serambi menggunakan bambu dan menggunakan plafon datar, sementara pada area panti imam dan panti umat menggunakan kayu dan bentuk plafon mengikuti kemiringan atap yaitu pelana. Penggunaan elemen yang berbeda pada tiap area juga dapat memperlihatkan adanya kualitas ruangan yang berbeda. Pembedaan elemen dapat terlihat pada bagian lampu dan kolom/struktur bangunan yang digunakan pada setiap area. Area yang tidak sakral (narthex) menggunakan elemen yang cenderung polos dan tidak terlalu mencolok, menunjukkan adanya sifat ruangan yang tidak terlalu penting, sementara area yang paling sakral (sanctuary) menggunakan elemen yang lebih besar dan mencolok, menunjukkan sifat ruangan yang paling penting/sakral.

Pada area sanctuary, tabernakel yang seharusnya masih memiliki kesatuan dengan panti imam, diletakkan di belakang, terpisah dari altar, kursi imam, mimbar, dan sebagainya. Peletakkan tabernakel di tempat yang terpisah yang benar-benar sunyi dan tenang merupakan cara Romo Mangun untuk menunjukkan bahwa tabernakel bersifat lebih keramat, sesuai dengan bagian Bait Tuhan di Yerusalem yang disebut Tabernakel atau Yang Suci dari Yang Suci sehingga diletakkan di ruangan yang bersuasana lebih terpingit sakral. Konsep pemisahan ruang tabernakel ini mengambil konsep luwangan (Paroki St. Maria Assumpta Klaten, 2013, p.34). Ide luwangan merupakan wujud inkulturasi budaya setempat (Jawa Tengah) dengan ketentuan Gereja Katolik.

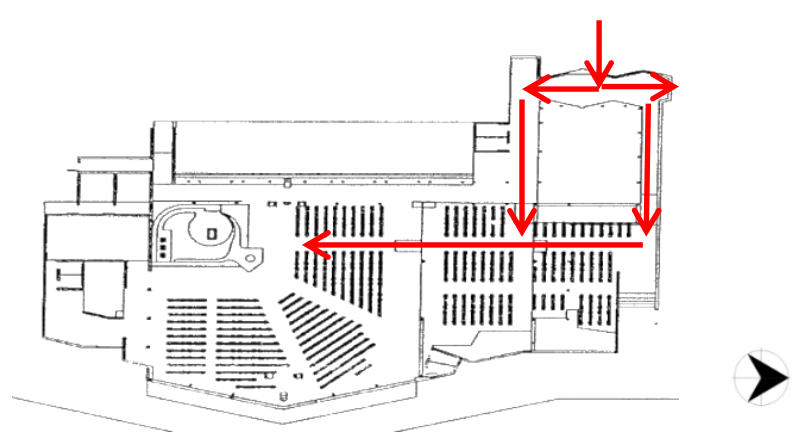

Figur 3. Axis Longitudinal pada Gereja Maria Assumpta

Axis Gereja Maria Assumpta bersifat terpatah-patah dan bercabang. Hal ini agak membingungkan jika dibandingkan dengan axis yang seharusnya bersifat lurus dan tegas menghubungkan ruang narthex, nave, dan sanctuary. Jalur yang bercabang bersifat "mengurangi" esensi dari sacred path tersebut.

\section{Gereja Theresia Salam}

Ruang dalam Gereja Theresia Salam dapat terbagi menjadi tiga, yaitu narthex, nave, dan sanctuary.

Pada Gereja Theresia Salam pembedaan kualitas ruang dilakukan melalui beberapa cara, diantaranya adalah melalui pembedaan elevasi lantai. Sama seperti Gereja Maria Assumpta, elevasi lantai tertinggi terletak pada sanctuary sebagai pusat dari perayaan liturgi Ekaristi. 


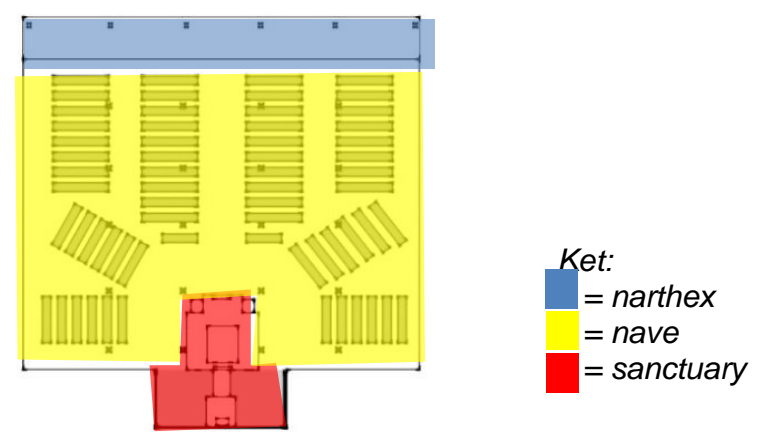

Figur 4. Tatanan ruang Gereja Theresia Salam

$\begin{array}{lcc}\text { Narthex Nave } 0.00 & \text { Panti imam } & +0.50 \\ -0.15 & & 0.00\end{array}$

Figur 5. Pembedaan elevasi lantai pada Gereja Theresia Salam

Cara lainnya adalah dengan pembedaan penggunaan material lantai pada area sanctuary dengan area lainnya untuk menunjukkan letak area yang paling sakral. Pembedaan proporsi ruang pada masing-masing area juga dilakukan untuk meningkatkan kualitas ruang sakral pada bagian sanctuary. Proporsi ini terutama terbentuk dari plafon yang memiliki ketinggian yang berbeda. Narthex sebagai area yang kurang sakral memiliki ketinggian plafon terendah dibandingkan area nave dan sanctuary. Sementara itu area nave dan sanctuary memiliki ketinggian plafon yang berbeda namun area sanctuary memiliki area plafon yang lebih luas dan memiliki bentuk utuh sehingga terasa lebih istimewa dibandingkan area nave.

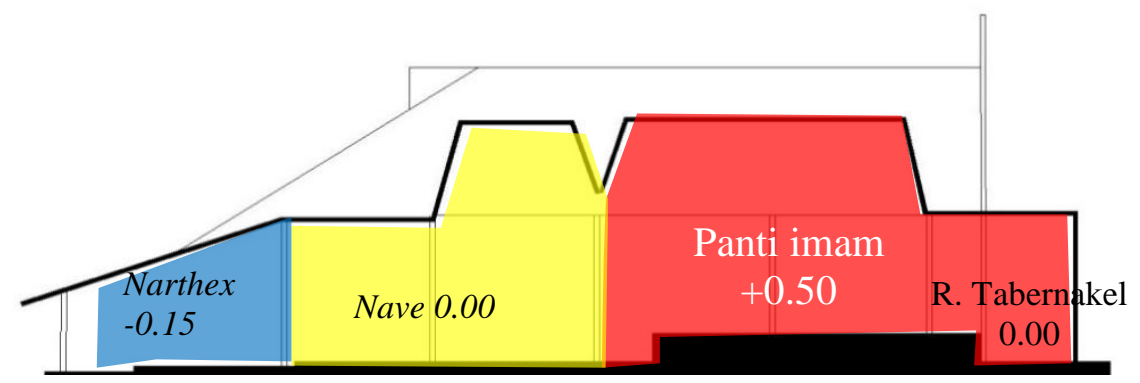

Figur 6. Potongan memanjang Gereja Theresia Salam yang memperlihatkan proporsi ruang

Seperti pada Gereja Maria Assumpta Klaten, pada Gereja Theresia Salam, tabernakel juga diletakkan di ruangan terpisah di belakang panti imam. Hal ini menunjukkan adanya perlakuan khusus pada tabernakel yang dilakukan oleh Romo Mangun sebagai salah satu bentuk penghormatan akan Tubuh dan Darah Kristus yang tersimpan di dalamnya. Meski terpisah, keberadaan tabernakel di Gereja Theresia Salam masih dapat dirasakan apabila tirai dibuka saat misa berlangsung.

Ruang dalam Gereja Theresia Salam (narthex-nave-sanctuary) memiliki kesatuan dan tidak ada pemisahan total yang terjadi di dalam ruangan. Namun pada bagian tengah ruangan terdapat kolom-kolom struktur yang mengakibatkan cukup terhalangnya pandangan umat yang duduk di area tertentu sehingga tidak semua umat dapat melihat ke arah altar dengan jelas. 
Axis Gereja Theresia Salam merupakan garis lurus yang menghubungkan ketiga ruang dalam (narthex-nave-sanctuary). Axis tersebut lebih tegas ditunjukkan dengan peletakkan ornamen pada kepala kolom bagian tengah (di kanan-kiri jalur sirkulasi utama) yang berbeda dengan ornamen kepala kolom pada bagian pinggir ruangan. Ornamen kepala kolom pada bagian tengah memiliki bentuk yang lebih rumit dengan ukuran yang lebih besar dibandingkan ornamen kepala kolom pada bagian pinggir ruangan, menunjukan adanya keistimewaan pada area yang diapit kolom dengan ornamen tersebut (merupakan sirkulasi utama dan area sanctuary).

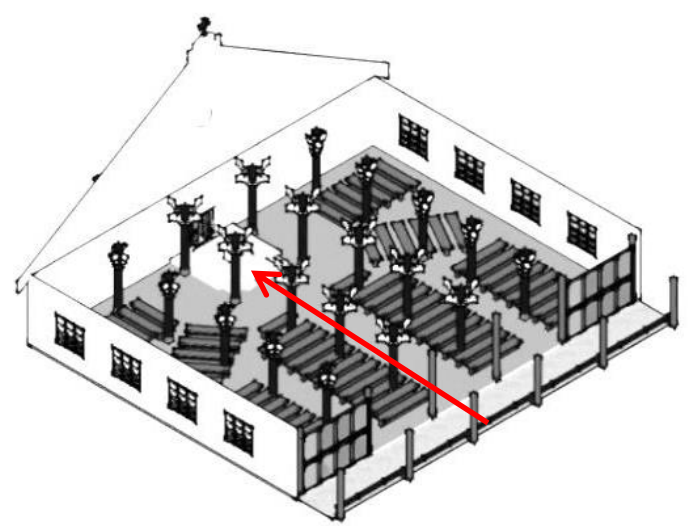

Figur 7. Aksonometri ruang dalam Gereja Theresia Salam memperlihatkan axis

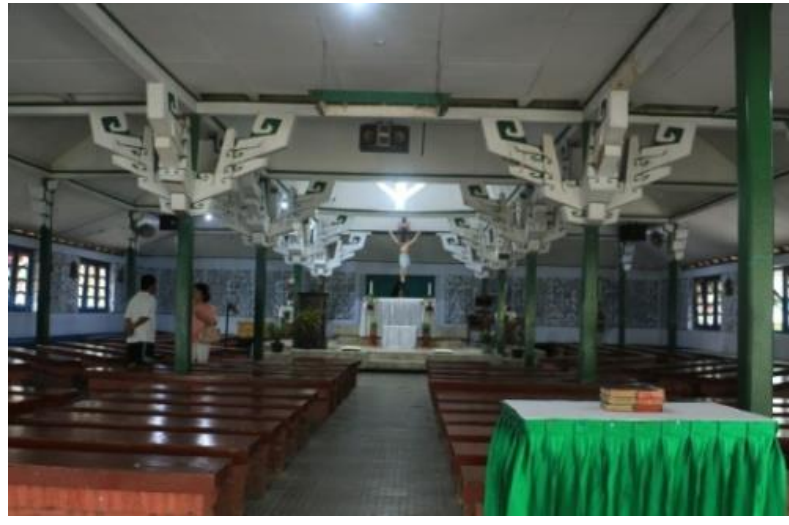

Figur 8. Sirkulasi utama yang menjadi axis pada Gereja Theresia Salam

\section{Gereja Maria Sapta Duka Mendut}

Terdiri dari narthex, nave, dan sanctuary. Bagian nave pada Gereja Maria Sapta Duka Mendut terbagi menjadi dua bagian yang terpisahkan oleh perbedaan penggunaan atap.
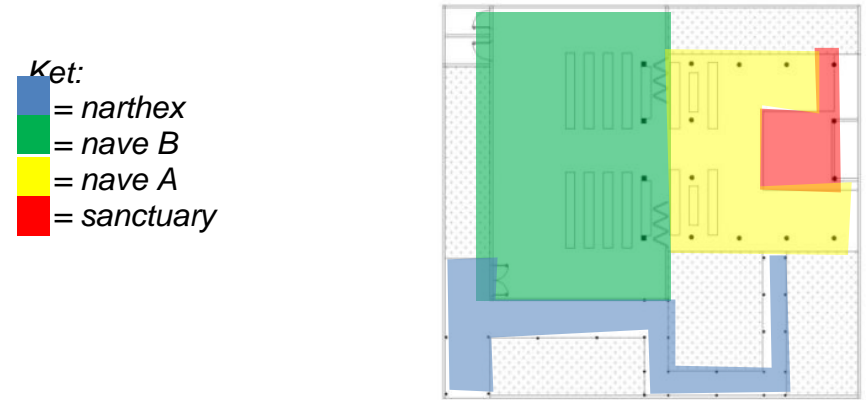

Figur 9. Tata ruang Gereja Maria Sapta Duka Mendut

Pada Gereja Maria Sapta Duka Mendut, pembedaan kualitas ruang antara narthex, nave, dan sanctuary dilakukan melalui beberapa cara, diantaranya adalah melalui perbedaan elevasi lantai sama seperti pada kedua obyek studi sebelumnya. Pembedaan lainnya adalah dengan pembedaan penggunaan material lantai dan penggunaan struktur kolom yang berbeda pada area narthex, nave $\mathrm{B}$, dan nave $\mathrm{A}$.

\begin{tabular}{cccc} 
& & Ruang \\
Narthex & Nave A dan Nave B & Panti imam & Tabernakel \\
-0.01 & 0.00 & +0.20 & +0.30 \\
\hline
\end{tabular}

Figur 10. Pembedaan elevasi lantai pada Gereja Maria Sapta Duka Mendut 
Ruang tabernakel pada Gereja Maria Sapta Duka Mendut meski diletakkan di ruang terpisah namun pelingkup dari ruang tersebut berupa kaca transparan sehingga masih terdapat kesatuan dengan panti umat. Selain itu terdapat pintu yang berada di tengah-tengah ruang tabernakel tersebut yang dapat dibuka saat misa berlangsung sehingga pandangan ke tabernakel dari panti umat masih dapat terlihat dengan jelas.

Sementara itu, axis yang tercipta pada Gereja Maria Sapta Duka Mendut bersifat terpatah-patah (tidak berupa garis lurus tegas) namun tidak bercabang. Axis yang terpatahpatah muncul akibat letak pintu masuk yang tidak berada ditengah-tengah ruangan. Axis yang bercabang bersifat lebih tidak sakral jika dibandingkan dengan axis yang bersifat lurus tegas.

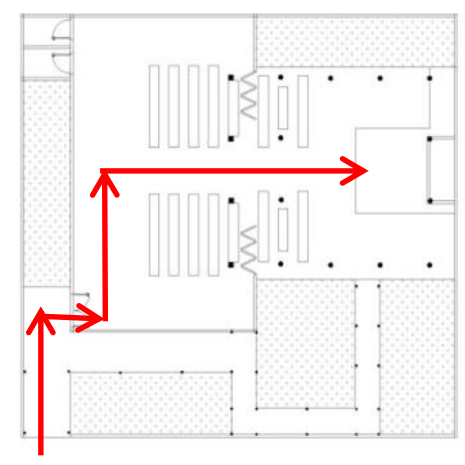

Figur 11. Axis pada Gereja Maria Sapta Duka Mendut

\subsection{ORIENTASI}

\section{Gereja Maria Assumpta Klaten}

Orientasi eksterior bangunan mengarah ke atas sesuai dengan bentuk atap segitiga yang mengerucut ke atas. Hal ini sebagai bentuk dari mengarah ke Tuhan (Yang Di Atas). Bentuk atap yang digunakan mengambil bentuk dari konstruksi tenda yang mengingatkan akan Tenda Penyimpanan Batu Perjanjian Tuhan dengan Israel di Gunung Sinai. Makna bentuk atap gereja yang mengingatkan akan bentuk atap tenda bangsa Israel mengingatkan bahwa fungsi gereja memiliki kesamaan dengan fungsi tenda Israel tersebut yaitu melindungi sesuatu yang sakral, tabut perjanjian dengan Yahwe.

Sementara itu, orientasi ruang dalam bangunan mengarah ke panti imam yang berada pada sudut diagonal ruang. Hal ini memungkinkan umat untuk mendapatkan fokus yang lebih baik terhadap panti imam.

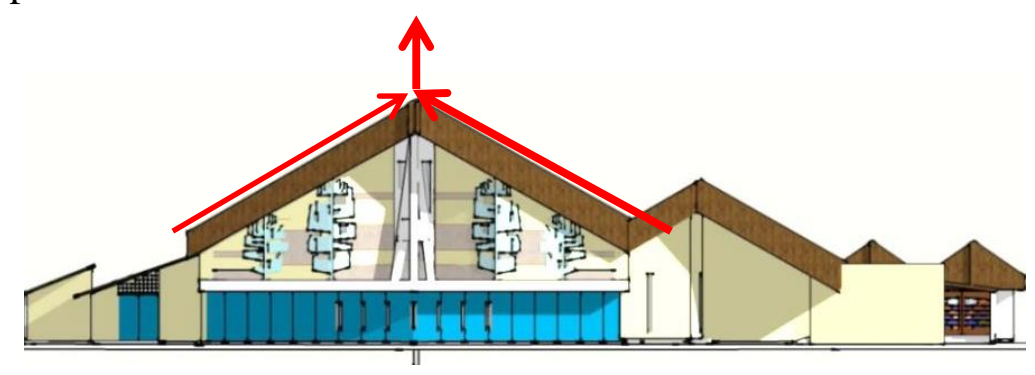

Figur 12. Bentuk atap Gereja Maria Assumpta yang tetap memiliki orientasi ke atas 


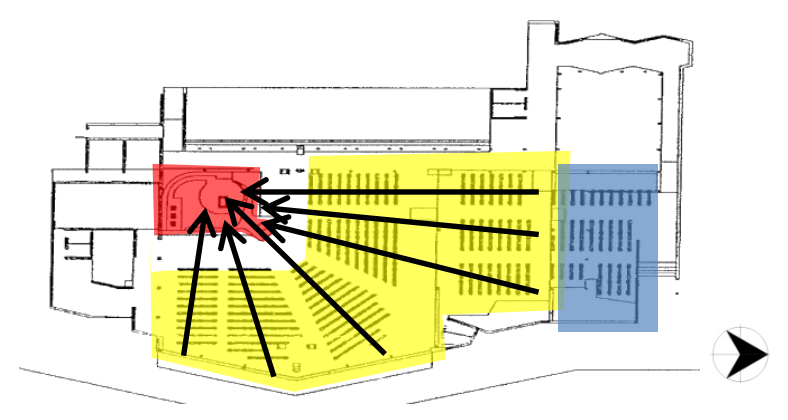

Figur 13. Orientasi interior pada Gereja Maria Assumpta

\section{Gereja Theresia Salam}

Bentuk atap bangunan memiliki orientasi ke atas dengan mengambil bentuk dasar segitiga (setengah atap perisai dan setengah atap pelana).

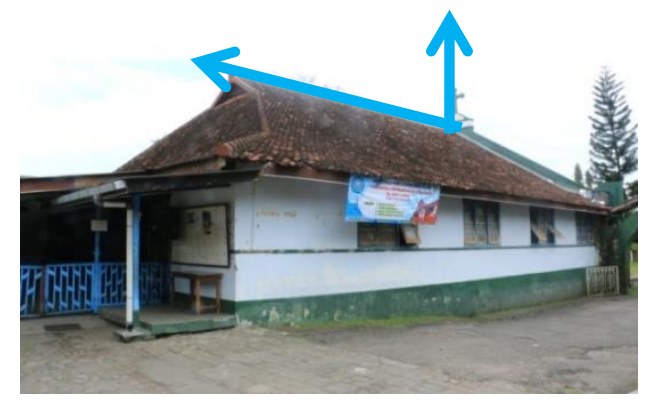

Figur 14. Bentuk bangunan Gereja Theresia Salam, memperlihatkan orientasi ke atas dan arah hadap ke Wisma Salam

Pada Gereja Theresia Salam, altar sebagai pusat dari orientasi diletakkan di tengah ruangan. Tempat duduk umat disusun dengan dua pola. Pada bagian depan tempat duduk umat ditata membentuk setengah lingkaran banyak arah, sementara tempat duduk umat di belakang ditata dengan pola satu arah. Tatanan setengah lingkaran banyak arah memungkinkan setiap kursi dapat melihat altar dengan jarak pandang yang relatif sama dibandingkan dengan tatanan satu arah. Namun karena bentuk denah bangunan adalah persegi maka pola tersebut tidak memungkinkan untuk diterapkan sampai ke belakang sehingga ada bagian kursi yang harus ditata dengan pola satu arah. Kursi pada bagian belakang yang ditata dengan pola satu arah kemungkinan tidak mendapat kualitas visual yang sama baik dengan kursi pada bagian depan yang ditata dengan pola setengah lingkaran.

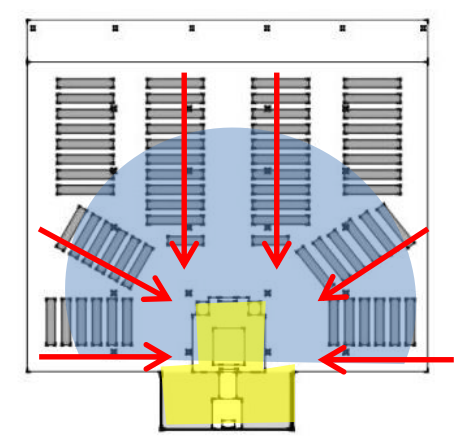

Figur 15. Tatanan interior setengah lingkaran Gereja Theresia Salam

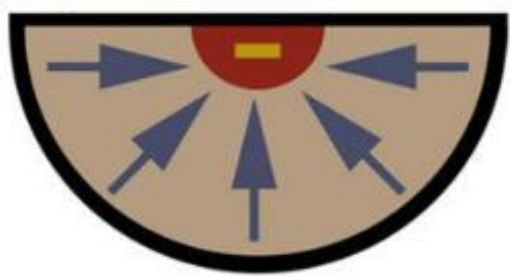

Figur 16. Pola interior setengah lingkaran banyak arah (Sumber: Srisadono, 2013) 


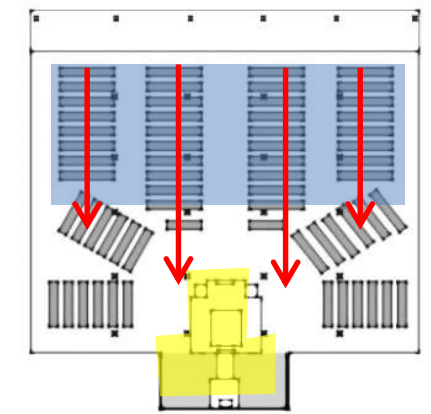

Figur 17. Tatanan interior pola satu arah Gereja Theresia Salam

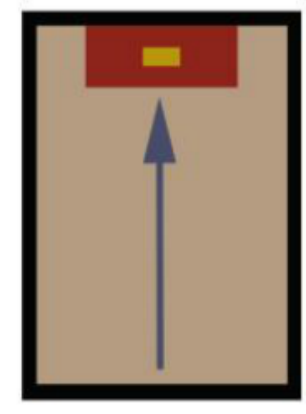

Figur 18. Pola interior satu arah (Sumber: Srisadono, 2013)

\section{Gereja Maria Sapta Duka Mendut}

Bentuk atap Gereja Maria Sapta Duka Mendut memiliki orientasi ke atas yang baik. Selain itu, orientasi ke atas yang kuat juga didukung oleh keberadaan menara yang berada di depan massa bangunan. Bentuk menara yang mengerucut ke atas memberi ekspresi orientasi ke atas yang sangat kuat.

Sementara itu, tatanan kursi umat mengarah ke altar sebagai pusat dari perayaan liturgi Ekaristi dengan pola satu arah. Pola ini memiliki beberapa keunggulan yaitu memiliki jalur sirkulasi utama yang jelas dan memungkinkan umat untuk melihat ke arah yang sama yaitu bagian muka altar.

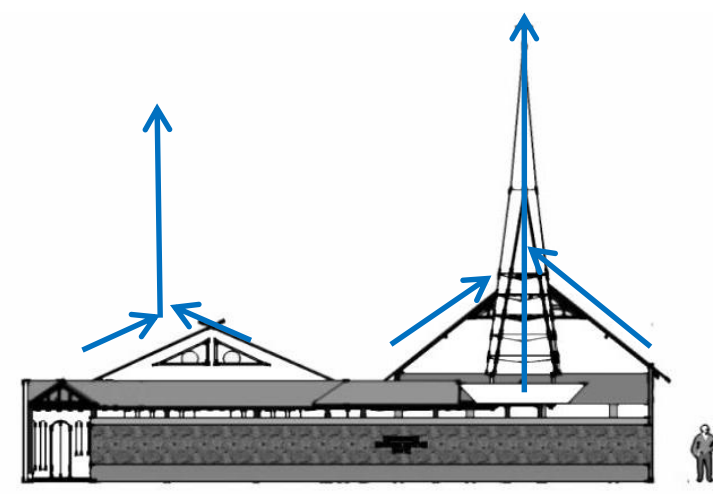

Figur 19. Tampak depan Gereja Maria Sapta Duka Mendut

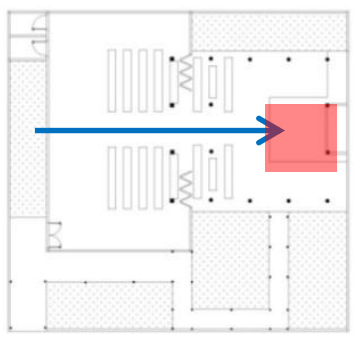

Figur 20. Orientasi interior Gereja Maria Sapta Duka Mendut

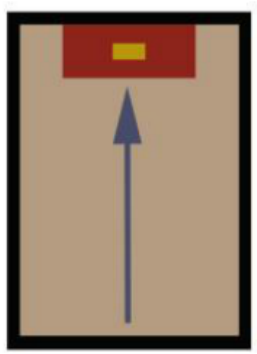

Figur 21. Pola interior satu arah (Sumber: Srisadono, 2013) 


\subsection{PROPORSI}

\section{Gereja Maria Assumpta Klaten}

Meskipun setiap ruang memiliki proporsi ruang yang berbeda-beda, namun jelas bahwa secara keseluruhan, ruang dalam Gereja Maria Assumpta memiliki proporsi horisontal yang lebih kuat. Kesan horisontal ini menunjukkan sifat gereja yang lebih keibuan atau dikenal dengan konsep Alma Mater ${ }^{8}$. Hal ini berbeda jika dibandingkan gereja-gereja Eropa pada umumnya yang memiliki ruang dalam dengan proporsi vertikal yang jauh lebih kuat untuk menghadirkan kesan keTuhanan yang sangat kuat.

Namun pada proporsi tersebut, sanctuary sebagai area terpenting dalam tatanan ruang dalam gereja memiliki ketinggian ruang terendah jika dibandingkan dengan ketinggian ruang lain, misalnya panti umat. Hal ini terjadi akibat adanya ketidaksesuaian antara bentuk bangunan dengan orientasi tatanan ruang dalam. Dari segi proporsi, sanctuary tidak mendapat tempat terpenting yang menunjukkan hirarki ruang tertinggi dalam tatanan ruang Gereja Maria Assumpta Klaten.

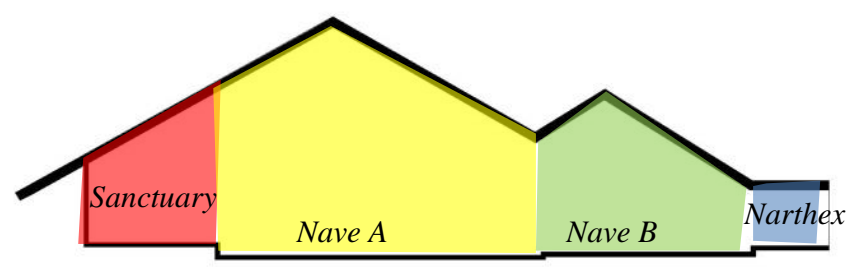

Figur 22. Proporsi ruang Gereja Maria Assumpta

\section{Gereja Theresia Salam}

Proporsi ruang dalam secara keseluruhan menunjukkan ekspresi horisontal yang lebih kuat dibandingkan ekspresi vertikalnya. Hal ini dapat dilihat dari proporsi keseluruhan ruang dalam yang memiliki ekspresi horisontal (lebar ruangan) yang kuat dibandingkan ekspresi vertikalnya (tinggi ruangan). Begitu juga proporsi bangunan yang memiliki ekspresi horisontal yang lebih kuat dibandingkan ekspresi vertikalnya.

Sifat horisontalisme yang kuat ini merupakan salah satu cara Romo Mangun untuk menanggapi hasil Konsili Vatikan II yang mengatakan bahwa Gereja tidak harus ditampilkan secara megah, tidak didirikan untuk mengejar kemuliaan duniawi, melainkan untuk menyebarluaskan kerendahan hati dan pengikraran diri. Oleh karena itu gereja dapat ditampilkan secara manusiawi, dengan proporsi bangunan dan ruangan yang bersifat horisontal dan menekankan aspek antropologis, menggambarkan Allah yang bersifat imanen (manusiawi) bukan bersifat transenden.

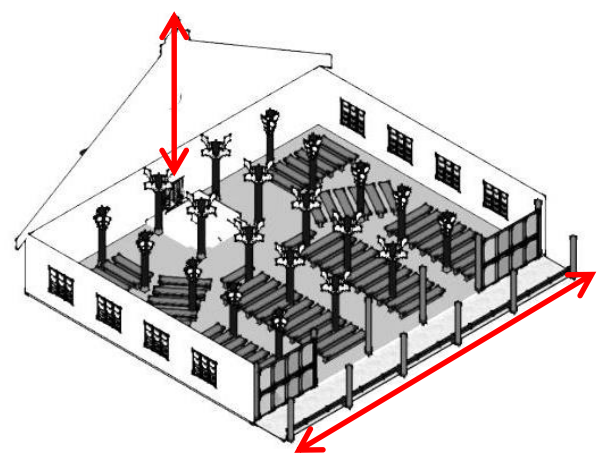

Figur 23. Aksonometri ruang dalam Gereja Theresia Salam, memperlihatkan proporsi ruangan 


\section{Gereja Maria Sapta Duka Mendut}

Gereja Maria Sapta Duka Mendut terdiri dari dua massa bangunan dan sebuah menara. Keberadaan menara ini pada bagian depan bangunan memunculkan ekspresi vertikal yang cukup dominan pada bagian eksterior bangunan.

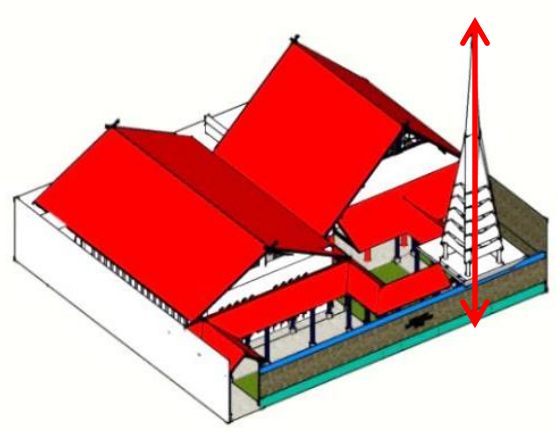

Figur 24. Aksonometri bentuk bangunan Gereja Maria Sapta Duka Mendut

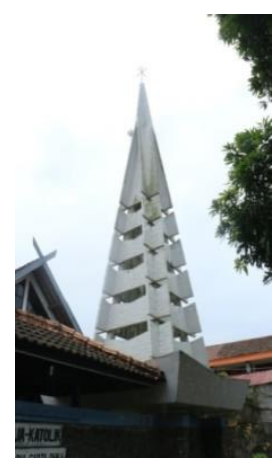

Figur 25. Menara pada Gereja Maria Sapta Duka Mendut yang menampilkan ekspresi vertical

Ekspresi vertikal tidak muncul pada bagian ruang dalam bangunan. Ruang dalam bangunan memiliki ketinggian plafon yang tidak terlalu tinggi jika dibandingkan dengan luas bangunan. Ekspresi horisontal yang dirasakan pada ruang dalam bangunan menunjukkan bahwa bangunan menampilkan aspek kemanusiaan yang lebih kuat. Tuhan dilambangkan sebagai sesuatu yang dekat dengan manusia, dan hidup bersama-sama dengan manusia, bukan sesuatu yang tinggi yang sulit diraih dan dicapai.

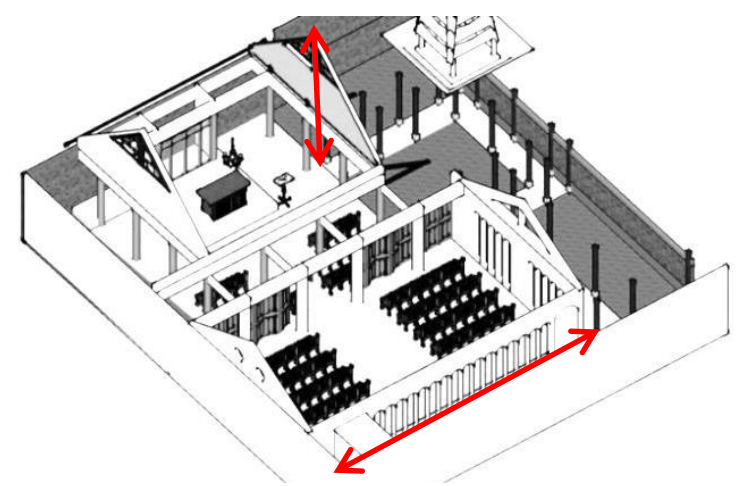

Figur 26. Aksonometri ruang dalam Gereja Maria Sapta Duka Mendut yang menunjukkan proporsi ruang dalam dengan ekspresi horisontal yang dominan

\subsection{ORNAMEN SAKRAL}

\section{Gereja Maria Assumpta Klaten}

Pada Gereja Maria Assumpta Klaten, ornamen sakral terdapat pada banyak elemen bangunan, diantaranya yaitu: (1) pada dinding panti imam, berupa gambar lima roti dan dua ikan sebagai pengingat dari peristiwa mukjizat penggandaan lima roti dan dua ikan yang dilakukan Yeus, (2) pada kolom terdapat gambar daun palma sebagai lambang kemenangan, (3) pada struktur utama, terdapat lambang keuskupan Agung Semarang dan lambang Garuda Pancasila yang melambangkan semboyan Pro Ecclesia et Patria (demi Gereja dan Tanah Air) atau bisa diartikan juga 100\% Katolik 100\% Indonesia (memberi identitas pada bangunan), (4) gambar pada salah satu bukaan berupa seorang wanita yang diduga adalah 
sosok Maria, (5) ornamen pada tabernakel berupa lidah api dan merpati sebagai lambang dari Roh Kudus, (6) ornamen pada kepala kolom yang melambangkan lidah api sebagai lambang dari Roh Kudus, (7) ornamen lampu dengan bentuk yang berbeda-beda sebagai representasi bentuk dari merpati yang merupakan lambang dari kehadiran Roh Kudus, serta (8) salib pada panti imam sebagai lambang kemenangan Kristus dan sebagai identitas kristiani.

Ornamen yang terdapat pada Gereja Maria Assumpta antara lain sebagai berikut:
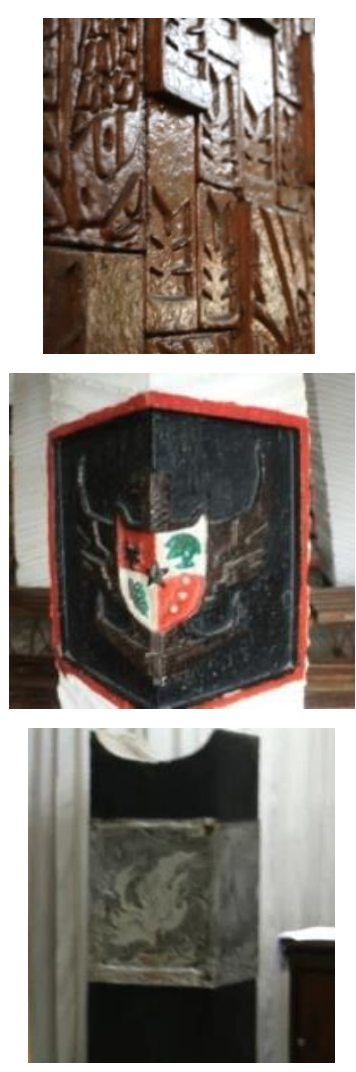
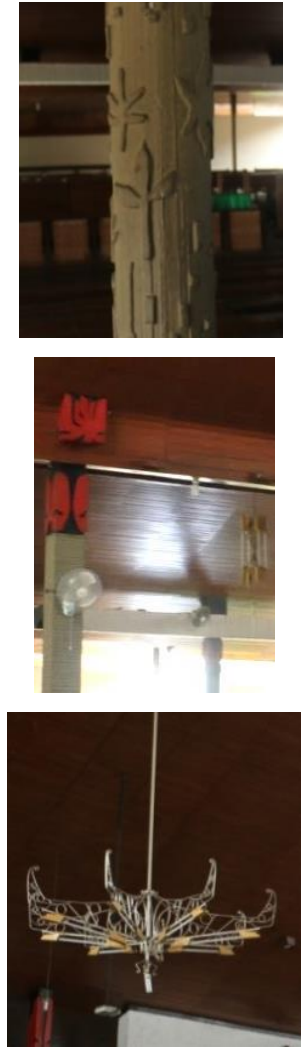
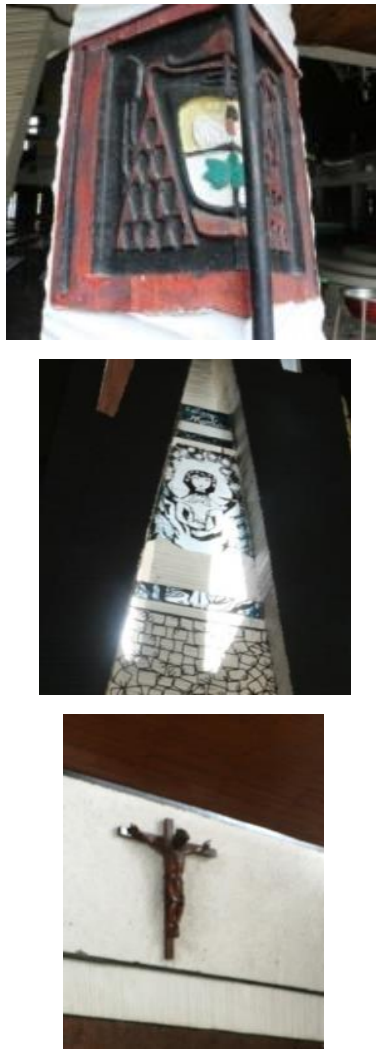

Figur 27. Ornamen sakral pada Gereja Maria Assumpta

\section{Gereja Theresia Salam}

Pada Gereja Theresia Salam, ornamen sakral terdapat pada beberapa elemen bangunan, diantaranya yaitu: (1) lukisan jendela yang menceritakan kisah-kisah suci yang terdapat dalam Alkitab. Lukisan pada jendela ini membuat jendela hampir memiliki tampilan yang sama dengan kaca patri pada gereja-gereja pada abad pertengahan, (2) ornamen pada plafon memiliki gambar merpati yang melambangkan kehadiran Roh Kudus, (3) ornamen pada dinding memuat beberapa gambar yaitu bulir-bulir biji gandum dan ilalang yang melambangkan Ekaristi, burung merpati yang merupakan lambang dari Roh Kudus, dan anggur yang merupakan lambang dari darah Kristus yang tertumpah di kayu salib, (4) salib utama yang terletak pada panti imam merupakan tanda kemenangan Kristus melawan kematian dan kejahatan. 

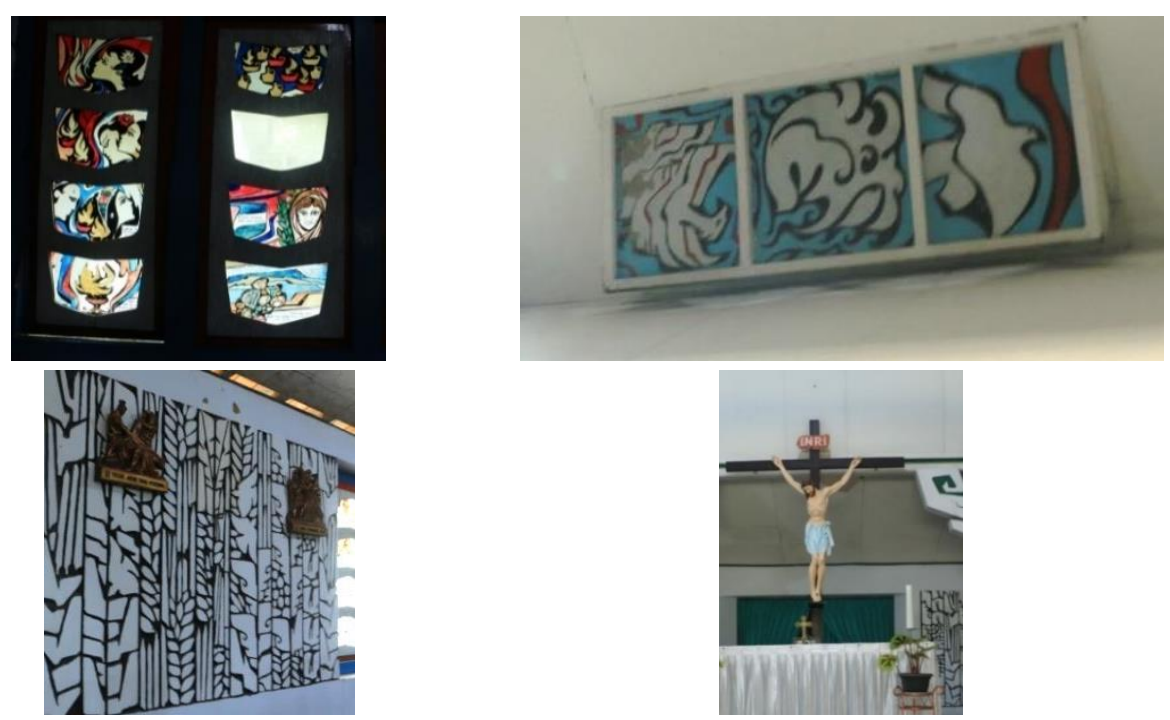

Figur 28. Ornamen sakral pada Gereja Theresia Salam

\section{Gereja Maria Sapta Duka Mendut}

Pada Gereja Maria Sapta Duka Mendut, tidak ada ornamen sakral yang menempel secara permanen pada bangunan. Ornamen sakral yang terdapat pada Gereja Maria Sapta Duka Mendut yaitu (1) lukisan jalan Salib yang memiliki gaya lukisan Jawa. Tokoh yang digambarkan pada setiap perhentian jalan salib digambarkan mengenakan pakaian adat Jawa bertujuan sebagai pemberi identitas lokal pada lukisan sekaligus pada bangunan, dan (2) salib sebagai tanda kemenangan Kristus.

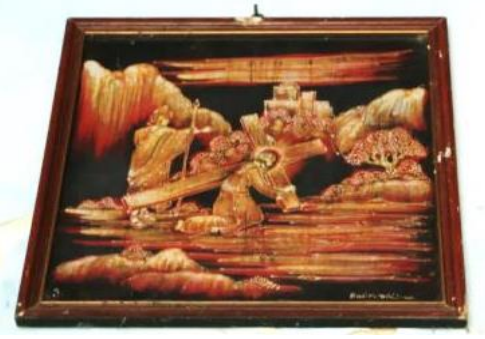

Figur 29. Salah satu lukisan perhentian jalan salib pada Gereja Maria Sapta Duka Mendut

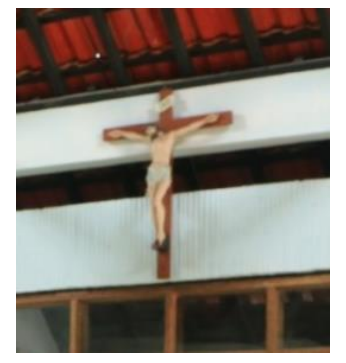

Figur 30. Salib pada Gereja Maria Sapta Duka Mendut

\section{SUASANA SAKRAL}

\subsection{GEREJA MARIA ASSUMPTA KLATEN}

\section{Cahaya liturgis}

Cahaya yang masuk ke dalam bangunan berasal dari pencahayaan alami dan pencahayaan buatan. Pencahayaan yang dominan adalah pencahayaan alami yang masuk ke ruangan melalui celah-celah, lubang, dan pintu lipat pada bidang dinding bagian timur dan barat. Efek pencahayaan yang ditimbulkan pada ruang dalam Gereja Maria Assumpta seringkali disebut sebagai cahaya surgawi karena efek cahaya yang masuk ke dalam ruangan menimbulkan siluet-siluet yang menghasilkan kesan ruang yang tidak biasa. Pencahayaan alami juga dimanfaatkan pada bagian atas tabernakel melalui skylight, sehingga tabernakel 
sebagai bagian paling sakral yang menyimpan Tubuh dan Darah Kristus menjadi sorotan utama dalam ruangan tersebut.
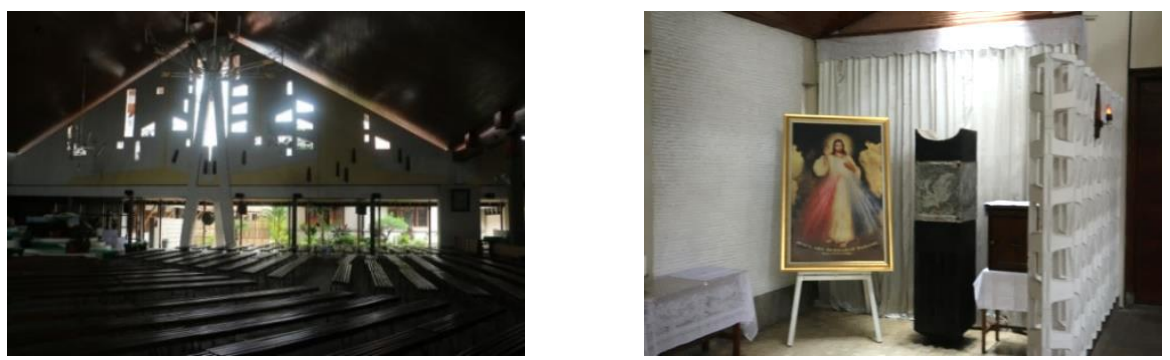

Figur 31. Pencahayaan alami pada Gereja Maria Assumpta

\section{Warna liturgis}

Warna-warna yang digunakan pada Gereja Maria Assumpta dan memiliki makna liturgis, antara lain: (1) kuning memiliki makna kemuliaan dan keabadian, kejayaan, kemurnian, (2) putih memiliki makna lambang kehidupan baru, simbol kemurnian, terang yang tak terpadamkan, kemuliaan abadi, dan kejayaan, dan (3) merah sebagai kontras dan simbolisasi dari Roh Allah yang menjadi pengilham dan peneguh hidup manusia, dapat juga melambangkan pertumpahan darah Kristus yang telah menebus dosa umat manusia

\subsection{Gereja Theresia Salam}

\section{Cahaya Liturgis}

Cahaya matahari masuk melalui kaca yang dilukis membentuk iluminasi cahaya yang dramatis di dalam ruangan. Pencahayaan yang ditimbulkan akan berwarna-warni, mirip dengan pencahayaan pada gereja abad pertengahan yang memanfaatkan kaca patri. Selain itu, pencahayaan pada bagian dalam ruangan difokuskan pada bagian panti imam sebagai bagian terpenting. Hal ini terlihat dari penggunaan lampu yang paling terang yang diletakkan di bagian atas panti imam. Pencahayaan yang seperti ini akan membawa umat untuk fokus ke panti imam sebagai pusat dari perayaan liturgi Ekaristi.

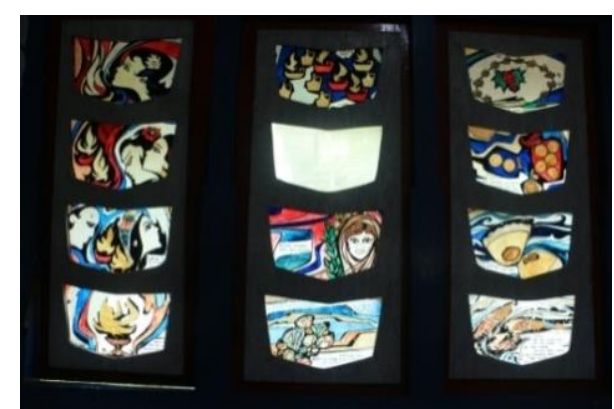

Figur 32. Penggunaan kaca lukis pada Gereja Theresia Salam

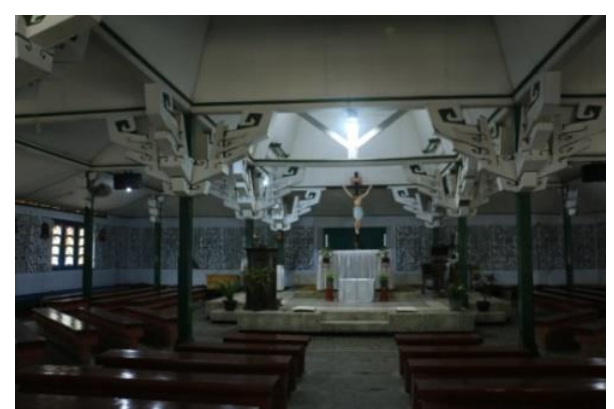

Figur 33. Pencahayaan ruang dalam Gereja Theresia Salam yang berfokus pada panti imam sebagai pusat dari perayaan liturgi Ekaristi

\section{Warna Liturgis}

Warna yang digunakan pada Gereja Theresia Salam yang memiliki makna liturgis antara lain adalah sebagai berikut: (1) putih melambangkan kehidupan baru, kemuliaan, dan kemurnian, dan (2) hijau melambangkan keheningan, ketenangan, dan kesegaran. 


\subsection{GEREJA MARIA SAPTA DUKA MENDUT}

\section{Cahaya Liturgis}

Bangunan dominan memanfaatkan pencahayaan alami sebagai penerangan di dalam bangunan pada siang hari. Semakin ke dalam ruangan (menuju nave A dan sanctuary) cahaya masuk ke dalam ruangan secara bebas. Adanya perubahan dari gelap menuju terang ini juga menunjukkan perbedaan kualitas ruang, dimana keberadaan Kristus lebih kuat pada ruangan yang lebih terang dan menerima banyak cahaya matahari (Kristus dilambangkan sebagai terang dunia).

Pada bagian sanctuary terdapat lampu gantung khusus yang dipasang untuk menerangi area tersebut. Pencahayaan khusus tersebut akan membantu umat untuk berfokus ke arah sanctuary selama perayaan liturgi Ekaristi berlangsung.

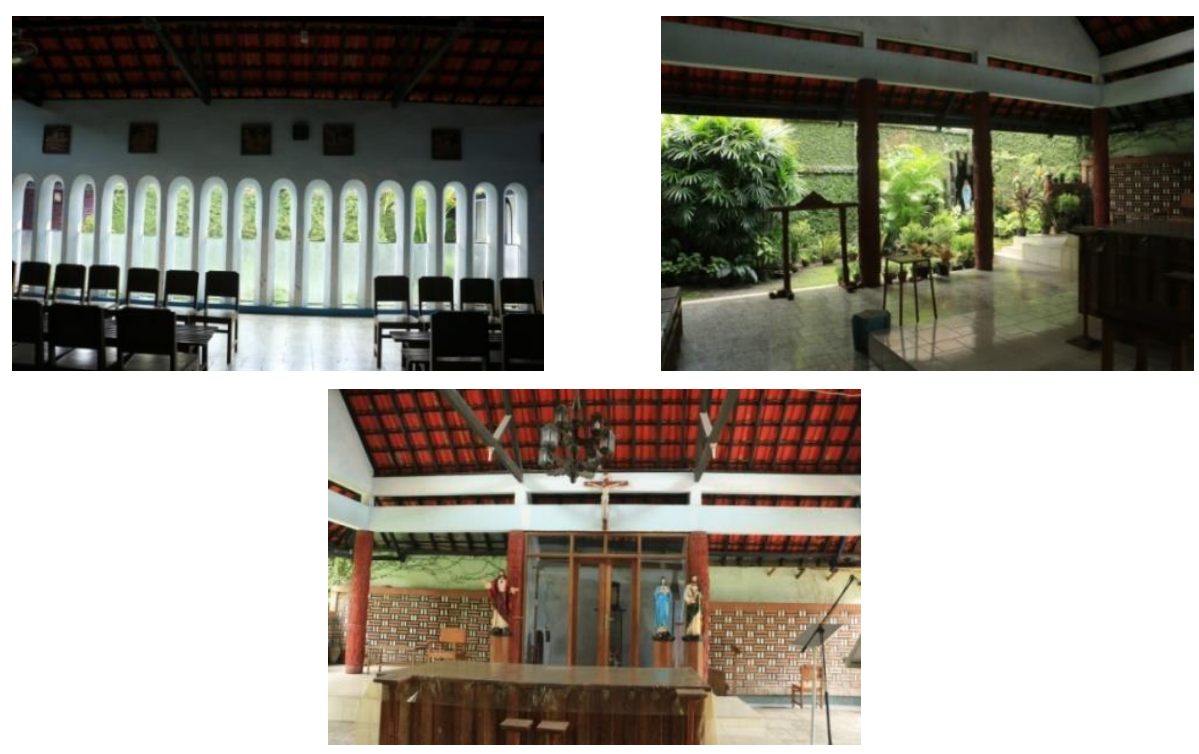

Figur 34. Pencahayaan pada Gereja Maria Sapta Duka Mendut

\section{Warna Liturgis}

Warna yang digunakan pada Gereja Maria Sapta Duka Mendut yang memiliki makna liturgis antara lain adalah sebagai berikut: (1) putih memiliki makna kehidupan baru, simbol kemurnian, kemuliaan, kebenaran mutlak, dan kejayaan, dan (2) merah melambangkan api dan terkait akan peristiwa penumpahan darah Yesus. Selain memiliki makna liturgis, warna merah ini juga memiliki makna sejarah dimana bangunan ini dibangun di atas puing-puing bangunan sebelumnya yang terbakar (ada unsur api).

\section{KESIMPULAN}

Ketiga obyek studi tidak ada yang secara keseluruhan memenuhi perwujudan ruang sakral Gereja Katolik, namun dari hasil analisa terhadap obyek studi dapat dilihat bahwa perwujudan ruang sakral pada obyek studi Gereja Katolik karya Romo Mangunwijaya ditinjau dari konsep dan perwujudan ruang sakral Gereja Katolik universal, paling kuat ditunjukkan dari segi orientasi, ornamen, dan suasana. Gereja-gereja obyek studi karya Romo Mangun sarat akan ornamen yang penuh makna liturgis kecuali pada Gereja Maria Sapta Duka Mendut. Pada Gereja Maria Sapta Duka Mendut, ornamen ditunjukkan hanya dengan 
lukisan dan salib yang bersifat tidak permanen (tidak menjadi bagian dari elemen bangunan), sementara pada Gereja Theresia Salam dan Gereja Maria Assumpta Klaten, ornamen sakral terletak pada banyak elemen bangunan seperti kolom, dinding, dan plafon. Orientasi eksterior dan interior pada ketiga obyek studi juga telah memenuhi prinsip simbolisme dan prinsip fungsi dan peran-serta dimana orientasi eksterior yang ditampilkan merujuk kepada Tuhan (Yang Di Atas) dan orientasi interior mengarah pada pusat dari perayaan liturgi Ekaristi yaitu panti imam (khususnya pada bagian altar).

Pada ketiga obyek studi, tatanan ruang paling baik ditunjukkan pada obyek studi Gereja Theresia Salam. Hal tersebut disebabkan oleh denah Gereja Theresia Salam yang simetris serta memiliki aksis longitudinal yang lurus dan tegas. Namun secara kesatuan ruang, Gereja Theresia Salam memiliki kolom di tengah ruangan sehingga ada beberapa bagian tempat duduk di panti umat yang terhalang saat melihat ke arah altar. Pada ketiga obyek studi, pembedaan kualitas ruang untuk menunjukkan hirarki dilakukan dengan berbagai cara diantaranya dengan pembedaan elevasi lantai, penggunaan material yang berbeda, serta penggunaan elemen yang berbeda.

Ketiga obyek studi memiliki proporsi (perbandingan lebar dengan tinggi bangunan) dengan ekspresi horisontal yang kuat. Hal tersebut sebagai bentuk tanggapan Romo Mangun atas Konsili Vatikan II yang menggambarkan gereja dengan rendah hati, bukan sebagai sesuatu yang megah. Pada Gereja Maria Sapta Duka Mendut, ekspresi vertikalisme masih dapat terlihat melalui elemen menara pada bagian depan bangunan.

\section{DAFTAR PUSTAKA}

\section{Buku}

Eliade, Mircea. (1957). The Sacred and The Profane. (diterjemahkan oleh Willard R. Trask). New York: Harcourt, Brace \& World, Inc. Hal 8-42.

Lolo, Irene Umbu \& Ujan, Bernardus Boli (Eds.). (2011). Liturgi Autentik dan Relevan. Maumere: Ledalero. Hal 34-46.

Martasudjita, E. (1998). Memahami Simbol-Simbol dalam Liturgi. Jogjakarta: Kanisius. Hal 50-58.

Pennick, Nigel. (1980). Sacred Geometry. Great Britain: Weatherby Woolnough

Suryanugraha, Harimanto. (2006). Rupa dan Citra: Aneka Simbol dalam Misa. Bandung: SangKris.

Windhu, I. Marsana. (1997). Mengenal 30 Lambang atau Simbol Kristiani. Yogyakarta: Kanisius.

\section{Skripsi, Thesis, dan Penelitian}

Kusbiantoro, Krismanto. (2003). Dominasi Makna Pragmatik YB. Mangunwijaya dalam Penerapan Konsep Konsili Vatikan II. Tesis tidak diterbitkan. Bandung: Universitas Katolik Parahyangan.

Lukita, Linda. (2004). Kajian Bentuk dan Makna Arsitektural Gereja Maria Assumpta. Skripsi tidak diterbitkan. Bandung: Universitas Katolik Parahyangan. Hal. 25-26, 30-36.

Srisadono, Yosef Doni. (2013). Konsep Ruang Sakral Gereja Katolik dan Perwujudannya dalam Inkulturasi Arsitektur Gereja Katolik Bali. Tesis tidak diterbitkan. Bandung: Universitas Katolik Parahyangan. Hal 21-24, 28-31, 49-105.

Subagio, Rudiyanto. (1997). Liturgi dan Arsitektur. Bandung: Lembaga Penelitian Universitas Katolik Parahyangan.

\section{Website}

Admin website Gereja Katolik St. Ignatius Magelang. (2010). Sekolah Poetri Mendoet. Diakses Lainnya tanggal 5 Maret 2017, dari http://www.ignatius-magelang.info/.

Paroki St. Maria Assumpta Klaten. (2013). Buku Kenangan 90 Tahun Paroki Santa Maria Assumpta Klaten. Klaten: (n.d) 